\title{
The Success of Google Search, the Failure of Google Health and the Future of Google Plus
}

\author{
Marcel Landeweerd ${ }^{1}$, Ton Spil ${ }^{1, *}$, and Richard Klein ${ }^{2}$ \\ ${ }^{1}$ Dept. of Industrial Engineering and Business IT, University of Twente \\ Marcel@landeweerd.nl, \\ a.a.m.spil@utwente.nl \\ ${ }^{2}$ Florida International University Miami, Florida, U.S.A. \\ kleinrich@yahoo.com
}

\begin{abstract}
What makes an e-commerce company successful? In 2011 24\% of venture capital in the US went into Internet companies adding up to a total of $\$ 6.9$ billion (PwC \& NVCA, 2011). With such high stakes the question of ecommerce success is more topical than ever. Google, one of the biggest ecommerce companies in the world, despite huge successful products like Google Search, has also seen failures. In this paper, we explore factors associated with successful and unsuccessful adoption of Google products using a literature study in conjunction with qualitative analysis of the Google Search, Google Health, and Google Plus products. Our research identifies key success factors for user adoption of Google products and predicts that Google Plus in its present form will lead to failure. The study shows that perceived compatibility, perceived usefulness, information quality, balancing risks with trust, and finally social pressure are important success factors for Google. Despite limiting the examination to Google products, results can serve as a guideline for other ecommerce ventures.
\end{abstract}

Index Terms: User adoption, User acceptance, E-commerce, Google, TAM.

\section{Introduction}

With the Internet integrated in all aspects of our society, fast growing Internet companies like Google and Facebook have become part of our daily lives as they have grown from small startup firms to multinational corporations in a matter of years. Despite economic difficulties in many countries, e-commerce continues to provide opportunity. Nevertheless, for every Internet success story, failures abound. Consider that Peapod and WebVan pursued similar online grocery initiatives. The former having started in the United Kingdom facing larger profit margins succeeded, while the latter fell victim to extremely narrow margins in the United States attracting few adopters. Similarly, WebMD rose to tremendous success drawing revenue from advertising and healthcare provider subscriptions; yet, DrKoop.com, attempting to capitalize on the reputation of its namesake, could not attract even a fraction of the user base of its competitor.

\footnotetext{
* Corresponding author.
} 
Even within the same firm some projects realize tremendous success while others fail. Explanations for success versus failure can be derived from user adoption of ecommerce. Looking at two projects from Google, we see both success and failure, with Google Search engine realizing widespread adoption (comScore, 2012), while Google's electronic personal health record (ePHR) under the name Google Health failed to reach a critical mass in audience (Google, 2011). Accordingly, user adoption constitutes a key concern, which leads to the question, "what yields user adoption of one e-commerce initiative and failure for another?"

The leading model in the area of user adoption is the Technology Acceptance Model (TAM) (Davis, 1989), which proposes usefulness, ease of use and attitude as leading success factors. A good runner up is the UTAUT model (Venkatesh et al, 2003); however, recent studies show that there is a lot of criticism specific to this model (Dwivedi et al, 2011). Both user adoption models do not fully cover all factors associated with user adoption of e-commerce as important domain specific factors including trust (Chervany, 2001-2002) (Corritore, Kracher, \& Wiedenbeck, 2003), service quality (Lee \& Lin, 2005), and risk (Lee M.-C. , 2009) remain unaddressed, many attempts have tried to extend the TAM model (Han \& Jin, 2009; Gefen, Karahanna, \& Straub, 2003; Chen, Gillenson, \& Sherrell, 2002) to cover e-commerce specific success factors. The Delone \& McLean Model of IS success (DeLone, 2003) constitutes another leading model and includes e-commerce specific measures. In contrast to the user focus of the TAM model, the D\&M IS Success Model views success more from the technology perspective looking at service quality, information quality and system quality as key determinants of user satisfaction. Despite sharing constructs and like propositions, no single model fully addresses all success factors of user adoption of e-commerce.

Employing a grounded literature search approach, we explore factors associated with user adoption of e-commerce explaining these in greater detail through interviews of potential Google product users. The next section provides background on evolution of Google's product offerings, followed by an in-depth review of our literature study of user adoption factors related to e-commerce. We then provide an overview of the research design and methodology; followed by a review of our results. Last, we discuss the findings and use our results to make a prediction for the future of Google's social network; Google Plus.

\section{Background}

E-commerce is a popular term associated with almost every business activity conducted on the Internet. The academic literature defines e-commerce very narrowly as "the buying and selling of information, products and services via computer networks" (Kalakota, 1997) to very broadly as "the sharing of business information, maintaining business relationships, and conducting business transactions by means of telecommunications networks." (Zwass, 1996). In order to keep focused on the transactional part of e-commerce, we adopt the narrow definition put forth by Kalakota and Whinston (1997). Noteworthy, buying and selling, not per definition, takes place via direct monetary transactions, but also by different means like showing adds, building user profiles, and other mechanisms of monetizing electronic services. 
Google is one of the biggest companies operating on the Internet. Using our definition, Google is considered an ecommerce company as the firm sells information and electronic services. Google does not draw direct money for these services, but monetizes services primarily through advertisements. Products of Google include both hugely successful products as well as ones that resulted in failure. This makes Google the ideal case to compare successful with unsuccessful ventures.

The first product studied is Google Search. Google Search started in March of 1996 as a research project of Larry Page and Sergey Brin, students at Stanford University. The project, name BackRub, sought to develop enabling technologies for a universal digital library (Google Inc., 2012). The new algorithm used links placed on the Internet (similar to academic citations), a technique known by the name PageRank. The new search engine adopted the name Google in 1997 and started a rapid growth trajectory that resulted in its first billion URL indexes by June of 2000, making it the largest search engine. Research identified Google as the most widely used search engine among students (Griffiths, 2005). By May of 2011 Google grew to the most visited website within the European Union with a reach of $94 \%$ of Internet users (comScore, 2012). By June of 2012 Google gained almost $67 \%$ of the United States market share (comScore, 2012), making Google the most successful search engine in the world.

The second product studied is Google Health. Google Health offers the user the opportunity to manage their own health information. Introduced in 2008 and retired on January $1^{\text {st }}$ of 2012, Google Health failed to capture widespread adoption achieving only limited use (Google, 2011). Google Health can be classified as an electronic personal health record (ePHR). ePHRs offer users a variety of advantages aimed at patient empowerment. Personal health records allow users to control their own information, creating a more balanced and complete view than current provider maintained health records (Ball, Smith, \& Bakalar, 2007). Further, ePHRs afford extra features such as making online appointments, supplemental information about illnesses, information about health care providers, self-care possibilities, and more (Pagliari, 2007 ). Sunyaev (2010) presents a framework for the evaluation of ePHRs based on functionality and adopts this to evaluate both Google Health as Microsoft Health Vault. Subsequently, finding it difficult to evaluate a service based only on end-user functionality.

The third product studied is Google Plus. Google Plus launched in June of 2011 as a rival to Facebook. Google Plus introduced the concept of circles as an easy way of dividing relations into groups and deciding what information to share with specific groups of people. This feature allows for better privacy settings, but has also seen debate given equivalent options available on Facebook (Desmedt, 2011). Further, Google Plus introduced hangouts, or a video chat function for groups of up to 10 people. This does not constitute Google's first attempt at launching a social network. Google Buzz started in 2010 ending a year later, Google Friend Connect launched in 2008 to retired in March of 2012. Orkut hit the market in 2004 with Google Brazil the only remaining operational unit in 2013. An important reason for Google to enter the social network market lies in harvesting user information, allowing Google to personalize both search results as advertisements (Poelhekke, 2011). 


\section{$3 \quad$ Literature Study}

An extensive literature search provides for an overview of the current academic insights in the area of e-commerce adoption. Academics have widely debated the topic of user adoption of e-commerce. Despite many valuable works in the area of user adoption of information system, we limited our search to literature applicable to user adoption of e-commerce, because of the different nature of IS adoption and the availability of sufficient literature on user adoption of e-commerce.

\subsection{Service Quality}

Service quality is of great importance for every company. Reducing defections by customers by only $5 \%$ has the potential to boost profits by as much as $85 \%$ to $100 \%$ (Reichheld \& Sasser, 1990). Good service quality increases good behavioral intentions and decreases bad behavioral intensions (Zeuthaml, Berry, \& Parasuraman, 1996), such as stimulating customer retention and improved loyalty versus preventing bad word-of-mouth communications. Given the impersonal nature of e-commerce, service quality is especially important to such transactions (Kim, Galliers, Shin, Ryoo, \& Kim, 2012) (Zeithaml, Parasuraman, \& Malhotra, 2002). Service Quality measurements for e-commerce tend vary broadly and include information quality, usability, and trust (Collier \& Bienstock, 2006) (Santos, 2012). In the context of our research, the inclusion of a broad service quality measure results in an "overall" quality measurement of the business enterprise. Hence, we chose a more limited measure focusing on support and customer service. Factors associated with service quality include quick responsiveness, assurance, empathy, reliability, follow-up service, and personalization (Liu \& Arnett, 2000) (Lee \& Lin, 2005).

\subsection{Information Quality}

Information quality influences both perceived usefulness (Green \& Pearson, 2011) (Chen \& Tan, 2004) and perceived usability mediated by trust (Zhou \& Zhang, 2009). Information quality can be measured in terms of accuracy, timeliness, completeness, relevance, and consistency (DeLone, 2003). Egger (2001) gives some guidelines for informational content, and these encompass product and service information, information about the company, and information limiting user risks. First product information should create value as well as instill credibility and transparency. Company information should present the firm, describe organizational achievements, and communicate company values; hereby increasing consumer trustworthiness and making it possible for the user to identify with the organization. Information that limits risks should include security and privacy policies in addition to contractual terms.

\subsection{System Quality}

System quality measures system design aspects and the way in which the system was built, through measures like usability, availability, reliability, adaptability, and response time (DeLone, 2003). Individual measures of system quality have overlap with other success factors in our study including perceived usability (Green \& Pearson, 
2011) and perceived usefulness, which encompass measures like system features (Kim, Galliers, Shin, Ryoo, \& Kim, 2012) (Urbach \& Müller, 2012). For the Web some specific measures exist such as security, valid links, page load times, search facilities, and anonymity (Aladwani \& Palvia, 2002).

\subsection{Perceived Usefulness}

Venkatesh et al. (2000) define perceived usefulness as "the extent to which a person believes that using the system will enhance his or her job performance", in other words, the system must deliver some value. Distinct from perceived usefulness (Wang, 2008), usefulness is often not objectively measurable, but rather a subjective perception of an individual user. Perceived usefulness consistently predicts purchase intention across a large variety of research contexts (Bhattacherjee, 2000) (Pavlou, 2003) (Venkatesh V. A., 2000) (Dubinsky, 2003) and is thereby an important CSF in e-commerce. Value derives in different ways including task-based timesavings, task ease enablement, as well as user entertainment and innovativeness. To deliver value, system use should incorporate efficiency, resulting in a close connection with perceived usability (Al-Gahtani, 2011).

\subsection{Perceived Usability}

Usability or ease of use defines how effortlessly a user can interact with a system. The International Standard Organization (ISO) defines usability as "the extent to which a product can be used by specified users to achieve specified goals with effectiveness, efficiency, and satisfaction in a specified context of use". Hence, usability is both user and goal specific, making it difficult to create universal guidelines; however, despite this, some practices likely prove more beneficial for many purposes. Consider, minimal clicks to reach a desired result (Hicks, 2002), placing important information before the page fold, clear navigation (Bhatia, 2002), use of breadcrumbs, good search possibilities (Freeman \& Hyland, 2003), read fonts, and cross browser compatibility. Research posits higher usability increases both perceived usefulness (Crespo, 2008) and intention to use (Bhattacherjee, 2000), but studies show weak, or no support, for a direct effect on intention to use (Chen \& Tan, 2004) (Klopping \& McKinney, 2004) (Crespo, 2008) (Shih, 2004).

\subsection{Trust}

The relative novelty of e-commerce and online shopping gives rise to greater (feelings of) uncertainty and risks. Hence, perceived risks and feelings of safety potentially drive the adoption of e-commerce, trust, or trustworthiness, an important and related underlying factor (Turban, 2011). Previous research shows trust as an important indicator of willingness to buy (Andrea Basso, 2001), particularly with respect to the initial purchase (Gefen, Karahanna, \& Straub, 2003) (Koufaris \& Hampton-Sosa, 2004) with a stronger influence than even perceived price (Kim, Xu, \& Gupta, 2012). Furthermore, trust is known to reduce perceived risks (Corritore, Kracher, \& Wiedenbeck, 2003). 
McKnight and Chervany $(2001,2002)$ define trust to encompass attitude, belief, intention, and behavior. Within the context of the current work, trust constitutes "an attitude of confidence formed by a combination of faith and knowledge that a second actor can and will perform as expected." The "will perform" implicitly encompasses the intention to do so, hereby capturing all four characteristics of trust as described by McKnight and Chervany (2001, 2002).

User privacy constitutes an additional issue for e-commerce firms. In a survey of 158 online users, privacy concerns ranked as the most important concern when transacting via the Internet at $55 \%$ of all respondents (Udo, 2001), highlighting the importance of privacy online. The right to privacy has existed for decades (Brandeis, 1890), but recent research shows users believe privacy a growing concern (Ackerman, 1999). That said, when using websites these same users take little to no precautions to protect their privacy online (Berendt, 2005) (Spiekermann, 2001) (Ackerman, 1999). Accordingly, users' willingness to disclose privacy-sensitive information to trusted organizations constitutes an important factor shaping e-commerce adoption.

\subsection{Perceived Risks}

By using an e-commerce service, users incur different risks. Lee (2009) identifies different perceived risks from the user perspective. Specifically, she identifies performance risk, social risk, time risk, financial risk, and security risks as facets of perceived risks (Lee M.-C. , 2009). Perceived risks has a negative influence on perceived usefulness, user attitude, and intention to use (Lee M.-C. , 2009) Lee, Park, \& and Ahn, 2001). In situations of higher risks, higher trust is also necessary as trust can reduce perceived risk (Corritore, Kracher, \& Wiedenbeck, 2003).

\subsection{Social and Personal Influence}

"Much of human behavior is not best characterized by an individual acting in isolation" (Bagozzi, 2007)

People are both influenced by their environment and their own attitude towards a specific e-commerce service and e-commerce in general. Attitude encompasses the sum of beliefs weighted by its evaluations (Miller, 2005). Hence, attitude implicitly derives from past experiences. Social pressure, a subjective norm (Venkatesh V. A., 2000) (Crespo, 2008), influences one's attitudes specific to intention to use (Venkatesh V. A., 2000) (Crespo, 2008). In an online context, social pressure can result from interactions with friends and acquaintances, but also from informational social influences (Lee, Shi, Cheung, Lim, \& Sia, 2011) like online reviews. The theory of planned behavior (Ajzen, 1991) adds perceived behavioral control as an influential factor explaining the difference between intention and actual behavior. Perceived behavioral control captures one's perception of internal and external controls that constrain a certain behavior.

\subsection{Perceived Compatibility}

Rogers (1983) defines compatibility as "the degree to which an innovation is perceived as consistent with the existing values, past experiences, and needs of potential adopters", and the degree to which an innovation is compatible can "either speed up 
or retard its rate of adoption" (Rogers, 1983) (Eastin, 2002). Karahanna et al. (2006) validates three distinct aspects of compatibility, namely, compatibility with prior experience, compatibility with existing work practices, and compatibility with values. These compatibility beliefs can be instrumental in shaping beliefs about usefulness and ease of use, and they also influence usage directly (Karahanna, Agarwal, \& Angst, 2006). In addition to the effect of compatibility on perceived usefulness and ease of use, compatibility also influences attitude (Hernández-García, Iglesias-Pradas, Chaparro-Peláez, \& Pascual-Miguel, 2010).

\section{$4 \quad$ Research Method}

The main question answered in this study is "What factors result into user adoption of one e-commerce product, or service, and not another?" We subsequently chose to examine Google because the firm is one of the biggest companies in e-commerce with both hugely successful products as well as ones that resulted in failure. The products selected for our research include Google Search, Google Health, and Google Plus. These products were selected because of sufficient availability of interview data and variation in success. Substantial market share (comScore, 2012) makes Google Search the pre-eminent success; Google Health retired in January of 2012 as a result of lagging interest (Google, 2011), classifying it as an unsuccessful venture. The success of Google Plus, one of the newest Google offerings, is still up in the air. Comparing characteristics of Google Search and Google Health derived from the interviews we can make a prediction regarding the potential user adoption of Google Plus.

\subsection{Interview Method}

We employ an interview model-based research method called PRIMA (Spil \& MichelVerkerke, 2012) (also known as USE IT) (Spil, Schuring, \& Michel-Verkerke, 2004), the model is based on a large body of knowledge including TAM (Venkatesh V. A., 2000), the Information System Success Model of Delone and McLean (2003) and the innovation diffusion model of Rogers (1983). The model has two dimensions; the innovationdimension and the domain dimension. The innovation dimension is separated into the process and the product. Both process and product determine the success of an innovation (Saarinen \& Sääksjärv, 1992). The domain-dimension is separated into the user domain and the information technology domain. The user domain primary covers factors associated with end-user adoption measurements. The information technology domain primary covers factors associated with quality of implemented system measures. This makes the method very suitable for studying adoption of e-commerce services. The qualitative research method is chosen to afford a more detailed understanding of the success measures, while complementing literature study with the interview method to allow the unraveling of the underlying end-user motivations. Further, few qualitative research initiatives in the area of e-commerce user adoption appear within the existing literature.

Data is collected by multiple interviewers that were trained to commence interviews using the PRIMA model (Spil \& Michel-Verkerke, 2012). This allows us to triangulate data using different interviewers and vary interviewees across different socio demographic criteria to improve validity (Miles \& Huberman, 1994). The interviewers where given the same instructions and question lists. 


\subsection{Interview Contents}

The PRIMA model (Spil \& Michel-Verkerke, 2012) consists of five areas of analysis, namely, (1) Process, (2) Relevance, (3) Information needs, (4) Means and people, and finally (5) Attitude. For our research primary the micro definitions of the constructs are used. In the following sections we explain which success factors we expect to measure by each construct. The validation of these expectations follow in the discussion.

Looking at the PRIMA method (Spil \& Michel-Verkerke, 2012), all success factors from our literature study are expected to appear either directly or indirectly as shown in table 1.

Table 1. Expected success factors to be measured by PRIMA construct

\begin{tabular}{|c|c|c|}
\hline $\begin{array}{l}\text { PRIMA } \\
\text { construct }\end{array}$ & $\begin{array}{l}\text { Success factors } \\
\text { expected to be } \\
\text { measured }\end{array}$ & Examples of questions asked \\
\hline Process & $\begin{array}{l}\text { Perceived } \\
\text { compatibility }\end{array}$ & $\begin{array}{l}\text { Which search engines you regularly use? Are you using a } \\
\text { fixed sequence of actions when searching online? Which } \\
\text { alternatives you have to find information? }\end{array}$ \\
\hline Relevance & $\begin{array}{l}\text { Perceived usefulness } \\
\text { Perceived usability }\end{array}$ & $\begin{array}{l}\text { Which functions of a search engine are most important for } \\
\text { you? Which parts of the system you experience as a } \\
\text { bottleneck? Do you have suggestions for improvements? }\end{array}$ \\
\hline $\begin{array}{l}\text { Information } \\
\text { needs }\end{array}$ & Information quality & $\begin{array}{l}\text { Which information you need to get from the service? Do } \\
\text { you get sufficient information from the system? Is the } \\
\text { information quality sufficient? }\end{array}$ \\
\hline $\begin{array}{l}\text { Means and } \\
\text { people }\end{array}$ & $\begin{array}{l}\text { Service quality } \\
\text { System quality } \\
\text { Perceived risks }\end{array}$ & $\begin{array}{l}\text { Do you get sufficient support? Is the system reliable? Does } \\
\text { the system offer enough privacy? }\end{array}$ \\
\hline Attitude & $\begin{array}{l}\text { Trust } \\
\text { Social and personal } \\
\text { influence }\end{array}$ & $\begin{array}{l}\text { Do you think IT is necessary to improve health information? } \\
\text { Do you feel social pressure of using the service? How much } \\
\text { time do you want to spend for learning to use the service? }\end{array}$ \\
\hline
\end{tabular}

\subsection{Interviewees}

Interviewees were given an introduction of the Google product and had the possibility to test the product before starting the interview, this to get familiarity with the Google product. As prescribed, our interviews should represent all homogenous groups (Yin, 1994). Drawing on the UTAUT (Venkatesh, Morris, Davis, \& Davis, 2003) model we include gender, age, and experience as moderators influencing the determinants of behavioral intention and actual use behavior. Previous research shows that experience positively influences adoption, while users that adopt one service express a greater likelihood to adopt another (Eastin, 2002) (Rogers, 1983) with perceptions evolving over time (Hernández, Jiménez, \& Martín, 2010). 


\subsection{Processing Interviews}

We obtained a total of 127 interviews among potential users of Google Search (46), Google Health (27) and Google Plus (54). These interviews represented different homogenous groups (Yin, 1994). First individual outcomes are extracted while scanning the interviews by using the success factors found in literature. Several studies have tried to extend existing models like TAM (Han \& Jin, 2009) (Gefen, Karahanna, \& Straub, 2003) (Chen, Gillenson, \& Sherrell, 2002) and the Delone and McLean model (Wang, 2008), while other work has integrated different models (Lee M.C., 2009) (Klopping \& McKinney, 2004). Despite sharing constructs and like propositions, no single model fully addresses all success factors of user adoption of e-commerce. Therefore, rather than draw upon a single model, we extract success factors identified across the literature and independently evaluate these factors using interview data. Success factors found by the extensive literature study are used as input for our research.

\section{$5 \quad$ Results}

First, we individually examine the interview outcomes for Google Search and Google Health. We then use these outcomes to draw an overall conclusion related to user adoption of Google products. We subsequently use this conclusion to predict potential user adoption of Google Plus.

\subsection{Google Search}

Different interviewers conducted a total of 45 interviews across the period 2008 till 2012. Experience with IT in general and search engines specifically fluctuated from very experienced to reasonable and moderate experience. Most were in the 15-25 age group (32), and the gender split was roughly equal (24 males, 22 females). All participants indicated a reasonable familiarity with Google Search with only two not using Google as their primary search engine, confirming the success in user adoption of Google Search.

In general older users need more time to find the right results, consistent with previous research findings (Freudenthal, 2001). Users expressed satisfaction with Google Search, noting ease of use in addition to fast, good, and well-organized results. Despite 7 users mentioning privacy concerns, it did not stop them from using Google.

All users see the value of Google, as the alternative would involve time consuming and potentially unsuccessful library searches. The perceived compatibility is high, while most users spent significant time behind the computer and using Google, as searching with Google fits into their work patterns. Sparse negatives mentioned specific to Google include sometimes not getting satisfactory results, too many results, the presence of commercial advertisements, and limited specialized information. These negatives did not, however, dissuade using Google Search. 
Table 2. Interview results Google Search

\begin{tabular}{|c|c|c|c|}
\hline Google Search & \multicolumn{2}{|l|}{$\checkmark$ Positive } & 3 Negative \\
\hline \multirow[t]{3}{*}{ Process } & \multicolumn{2}{|c|}{$\begin{array}{l}\text { Compatible with current (work) practices } \\
\text { and experiences }\end{array}$} & \\
\hline & Frequent usage & Little usage & \\
\hline & $\begin{array}{l}\text { Small usage } \\
\text { sessions } \\
\text { Usage pattern } \\
\text { Study \& Work }\end{array}$ & $\begin{array}{l}\text { Long usage } \\
\text { sessions } \\
\text { No fixed pattern } \\
\text { Hedonic \& Work }\end{array}$ & \\
\hline Relevance & \multicolumn{2}{|c|}{$\begin{array}{l}\text { Getting the right results } \\
\text { Fast results, Well-organized } \\
\text { Advanced search options } \\
\text { Objective, Complete, Simple }\end{array}$} & $\begin{array}{l}\text { Wrong results } \\
\text { Commercial adds } \\
\text { To much results } \\
\text { Privacy concerns }\end{array}$ \\
\hline $\begin{array}{l}\text { Information } \\
\text { needs }\end{array}$ & \multicolumn{2}{|c|}{$\begin{array}{l}\text { Trusting the information } \\
\text { Fast results, Simple, Trustworthy, } \\
\text { Freely accessible }\end{array}$} & $\begin{array}{l}\text { Limited specialized and technical } \\
\text { information, Too much information } \\
\text { Not relevant enough }\end{array}$ \\
\hline $\begin{array}{l}\text { Means and } \\
\text { people }\end{array}$ & \multicolumn{2}{|c|}{ Free , Easy accessible } & \\
\hline Attitude & \multicolumn{2}{|c|}{$\begin{array}{l}\text { Environment positive, Innovative } \\
\text { Positive experiences in past }\end{array}$} & \\
\hline
\end{tabular}

\subsection{Google Health}

In 2012, different interviewers conducted a total of 27 interviews. The experience among interviewees with ePHR was very limited. Most were in the 15-25 age group (15), and the gender split was roughly equal (11 males, 16 females). Most users didn't know of Google Health prior to the interview and only one actually used Google Health. Privacy concerns emerged as the biggest threshold for users with 23 out of 27 noting the issue as a big concern. Out of all the interviews emerges a view that users consider health information as very personal with a commercial company like Google not trusted with this information.

The second threshold is usefulness of the e-commerce service. Despite some positive reactions, most of the interviewees failed to see the direct value of Google Health for themselves. Currently, they do not hold their own health information, so why would they need to in the future? This indicates a low compatibility with current practices. Additionally, they noted relative good health as a reason not to use such eHealth systems. When asked if they saw barriers to using Google Health, one participant noted:

"... in addition to the fact that I don't have any information to put onto Google Health, I really would want privacy guarantees before putting my information into the system to prevent my information getting public on the internet"

This sentiment illustrates the general opinion emerging from the interviews.

The main problems, or objection points, are highlighted within the table below. Users do not see the relevance of Google Health with primarily negative attitude towards the product 
Table 3. Interview results Google Health

\begin{tabular}{|c|c|c|}
\hline Google Health & $\nabla_{\text {Positive }}$ & $\boldsymbol{X}_{\text {Negative }}$ \\
\hline Process & & $\begin{array}{l}\text { Time consuming } \\
\text { Currently calling doctor to get medical information, } \\
\text { almost no time in current efforts. }\end{array}$ \\
\hline Relevance & $\begin{array}{l}\text { Maybe useful for } \\
\text { other people }\end{array}$ & $\begin{array}{l}\text { No need } \\
\text { Security concerns }\end{array}$ \\
\hline $\begin{array}{l}\text { Information } \\
\text { needs }\end{array}$ & $\begin{array}{l}\text { Simple looking } \\
\text { Clear results }\end{array}$ & $\begin{array}{l}\text { Only available in English } \\
\text { Usage of medical terms } \\
\text { Concerns about quality when filling in data yourself } \\
\text { Current information enough }\end{array}$ \\
\hline $\begin{array}{l}\text { Means and } \\
\text { people }\end{array}$ & $\begin{array}{l}\text { Easy accessible } \\
\text { Free }\end{array}$ & $\begin{array}{l}\text { Support needed } \\
\text { Privacy risks }\end{array}$ \\
\hline Attitude & $\begin{array}{l}\text { Trust Google More } \\
\text { than Facebook }\end{array}$ & $\begin{array}{l}\text { No trust, Privacy concerns } \\
\text { No social pressure to use, No added value }\end{array}$ \\
\hline
\end{tabular}

\subsection{Google Plus}

Different interviewers conducted a total of 53 interviews during 2012. Again the majority were in the 15-25 age group (41) with an even gender split (20 males, 23 females). Every user had some experience with social media, varying between sometimes using YouTube to classifying themselves as being an expert. The most popular platform mentioned was Facebook, which was used by almost all interviewees. Users employed social media primary to stay in touch with friends both nearby and far away. Other goals include sharing study and work information and using it for fun or killing time.

Most interviewees (45 out of 53) had heard of Google Plus with only 4 using it. The main reason for this is that none of their friends are using Google Plus. Users adopting Google Plus primary use it for work in the Internet industry like online marketing and programming. So it seems Google Plus has not realized widespread adoption, but a niche of users employ the product. When asked about the advantages of Google Plus, 24 users saw advantages compared to 29 perceiving disadvantages. The advantages found are primary the use of circles and the possibilities for video chat, but as many users noted, this is also possible with Facebook. The concept of circles has been received positively, while users like to separate, for example, work and friends. This indicates that their view of social relations is in line with the concept of circles. Users only see small differences with current social media available, which is an indicator of good compatibility. All users mention privacy concerns when using social media, this is not a reason to stop use, but a reason to be careful with what to share. Many users neither trust Google nor Facebook with their information, but 21 have a preference for Google compared to 8 having a preference for Facebook. Through all interviews there emerges a view of minor advantages against a big disadvantage due to lack of friends on Google Plus, i.e., a requisite critical mass. Looking at our success factors from literature, usefulness, information fit, social pressure, and trust, we see that Google Plus has a low usefulness due to a lack of critical mass, there is a bad fit with information needs while no friends are using Google Plus resulting in a lack of information about friends and no social pressure to use Google Plus. Only 
trust of Google emerges higher, which may result in a higher willingness to use. To reach a widespread user adoption Google needs user information, while user adoption seems necessary to get this user information. To become a success Google needs to find an answer to this causality dilemma, otherwise Google Plus will follow Google Health in its early retirement.

Table 4. Interview results Google Plus

\begin{tabular}{|c|c|c|}
\hline Google Plus & ( Positive & 3 Negative \\
\hline Process & $\begin{array}{l}\text { Keeping in touch with friends } \\
\text { Just for fun } \\
\text { Sharing study and work information } \\
\text { Ability to separate work and friends } \\
\text { Google plus almost the same as } \\
\text { currently used Facebook }\end{array}$ & $\begin{array}{l}\text { Social media in general distracting } \\
\text { from normal activities }\end{array}$ \\
\hline Relevance & $\begin{array}{l}\text { Option for group video } \\
\text { Ordering relations in groups } \\
\text { Good usability } \\
\text { Integration with other Google products }\end{array}$ & $\begin{array}{l}\text { Copy of Facebook } \\
\text { Options also available on Facebook } \\
\text { Not enough advantages to switch }\end{array}$ \\
\hline $\begin{array}{l}\text { Information } \\
\text { needs }\end{array}$ & $\begin{array}{l}\text { Same possible information as Facebook } \\
\text { Tech information available }\end{array}$ & $\begin{array}{l}\text { No information because of lack of } \\
\text { friends }\end{array}$ \\
\hline $\begin{array}{l}\text { Means and } \\
\text { people }\end{array}$ & $\begin{array}{l}\text { Easy accessible } \\
\text { Free }\end{array}$ & Risks of bad privacy \\
\hline Attitude & Trust Google More than Facebook & $\begin{array}{l}\text { No social pressure to use } \\
\text { Only using when friends use it } \\
\text { Don't see really big advantages }\end{array}$ \\
\hline
\end{tabular}

\section{Discussion}

The value of compatibility as a success factor was supported. Google Search fits well with current work practices that often included working many hours behind a computer. Further users were already familiar with the way the search engine works and presents results. In the case of Google Health, low compatibility prevailed as users currently didn't administer their own Health information and didn't see the value of doing so. Current practices included calling the doctor, which was less time consuming. Keeping an ePHR is seen as a task for medical specialist, and accordingly, Google Health seems incompatible with existing practices (Rogers, 1983). In the case of Google Plus, compatibility seemed positive. While there were not big differences with existing social media, the concept of circles was in line with their view of social relationships. A higher compatibility increases the perceived usefulness of a service (Karahanna, Agarwal, \& Angst, 2006) (Hernández-García, Iglesias-Pradas, ChaparroPeláez, \& Pascual-Miguel, 2010), this is both supported by the literature and our study.

The usefulness of the service is in line with literature and demonstrated an important success factor. The usefulness of the services differs with all seeing Google Search as useful, or even essential, and viewing Google Health as of limited usefulness. Participants do not currently retain their personal health information and fail to 
see added value in doing so. The alternative to Google Health, calling the doctor seems easy and fast. By comparison, the difficult and time-consuming alternative to Google Search necessitates visiting a library. Hence, users considered the functionality of Google Plus similarly useful and easy to use, but the overall usefulness of Google Plus as a service emerged as low because of a lack of friends who use Google Plus, an essential part of social media. . In that context the relative advantage construct of Rogers (1983) seems more appropriate than the perceived usefulness construct of TAM (Venkatesh V. A., 2000). The usability of all three services was viewed favorably by interviewees.

Information needs align closely with usefulness of the e-commerce service as usefulness of services rests in providing the right information. Users expressed positive sentiments about the information provided by Google Search classifying it as reliable, simple, and fast. Users of Google Health, however, saw providing their own information as unreliable with usage of medicinal terms complicated. Not all interviewees deemed the information provided by and use of Google Health negatively, failing to see relevance to their own situation, which resulted in a bad fit to their specific situation. This result supports the theory saying that the better the fit between information needs and information provided by the e-commerce service, the higher the user adoption of the service. Our analysis of Google Plus revealed the service lacked information. While users like to receive updates from friends, many were not Google Plus users.

Consistent with the theory of planned behavior (TPB) (Ajzen, 1991), sufficient means implies external controls influence both intention to use and actual use. All services saw no restrictions to use the service with the Internet and computers readily available and requisite knowledge sufficient, resulting in users making little to no use of customer support. Widespread acceptance of the Internet, mitigates restrictions on searches to use Google products. Also, system quality was considered good with all services fast and no availability problems mentioned. Only Internet problems at home or at work were mentioned, but these problems were not related to Google. Furthermore users didn't see the need of contacting Google's customer service, while all necessary information was readily available online.

Our literature search found that the social pressure of using a service will increase the likelihood the user consistently uses the service. Our interviews showed that there was an absence of social pressure to use Google Health, while Google Search saw significant pressures. In the case of Google Plus, there is a lack of social pressure in the absence of a critical mass of friends using the service.

A balance between trust and risk is necessary. The results of our interviews support this proposition. Despite users trusting Google with their search queries, they are very reticent to share personal health information, as users considered this information far more personal and privacy-sensitive. In other words, the perceived risks of Google Health are higher than the perceived risks associated with Google Search. The most plausible explanation lies in a negative correlation between trust and risks, in other words trust should be in balance with risk. Google Health carries higher risks necessitating greater trust. Conversely Google Plus users expressed privacy concerns, but trusted Google more than Facebook, which they already used. So in the case of Google Plus, trust seems sufficient. Many studies used trust as a success factor, but few studies recognize the relationship to risk. Our study showed evidence that trust can't be seen as an 
isolated factor, but should be viewed as inseparably couple. In situations of high risk, high trust is necessary as trust can reduce specific risks perceptions.

Table 5. Success factors in literature with findings at Google

\begin{tabular}{|c|c|c|c|c|c|c|c|}
\hline & $\begin{array}{l}\text { Google } \\
\text { Search }\end{array}$ & $\begin{array}{l}\text { Google } \\
\text { Health }\end{array}$ & $\begin{array}{l}\text { Google } \\
\text { Plus }\end{array}$ & & $\begin{array}{l}\text { Google } \\
\text { Search }\end{array}$ & $\begin{array}{l}\text { Google } \\
\text { Health }\end{array}$ & $\begin{array}{l}\text { Google } \\
\text { Plus }\end{array}$ \\
\hline $\begin{array}{l}\text { Service } \\
\text { quality }\end{array}$ & $v$ & 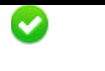 & $\theta$ & $\begin{array}{l}\text { Perceived } \\
\text { risks }\end{array}$ & Low & High & Medium \\
\hline Information & $\theta$ & $\boldsymbol{x}$ & $\boldsymbol{X}$ & Perceived & $\boldsymbol{V}$ & $\boldsymbol{x}$ & $\boldsymbol{x}$ \\
\hline $\begin{array}{l}\text { quality } \\
\text { System } \\
\text { quality }\end{array}$ & $\theta$ & 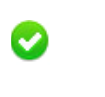 & $\theta$ & $\begin{array}{l}\text { Social and } \\
\text { personal }\end{array}$ & 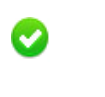 & $\boldsymbol{x}$ & $\boldsymbol{x}$ \\
\hline Trust & $\theta$ & $\mathbf{X}$ & $\theta$ & $\begin{array}{l}\text { influence } \\
\text { Perceived } \\
\text { compatibility }\end{array}$ & 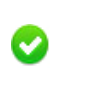 & $\boldsymbol{x}$ & 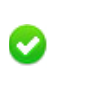 \\
\hline $\begin{array}{l}\text { Perceived } \\
\text { usability }\end{array}$ & $\theta$ & 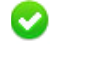 & $\theta$ & & & & \\
\hline
\end{tabular}

\section{Strengths and Weaknesses of Study}

The number of qualitative studies in the area of e-commerce user adoption is limited. The combination of an extensive literature search with a qualitative analysis using interviews of potential Google users constitutes a unique contribution. The qualitative method allows us to see relationships between success factors, which would be unknown using a quantitative approach. The study explains the user adoption of Google Search and the failure of Google Health. Last, but not least, the study shows the causes plaguing Google Plus adoption.

Our research has several limitations. Different interviewers conducted the interviews, the risks of biasing the results by the interviewers is limited by giving these interviews the same protocols and instructions and above all an extensive training. The subject of our interviews, Google products, restricts our findings to a single firm but since the products are three totally different e-commerce services we strongly belief the result can be generalized to all e-commerce services. The products researched were free to use with information the primary value, potentially resulting in a close relation between information quality and usefulness. This doesn't neglect the value of the method used. The widespread adoption of Google Search resulted in sample of users familiar with the product, with this knowledge possibly influencing interview results.

\section{Conclusion and Implications}

This study combined an extensive literature search with a total of 127 interviews among potential users of Google Search (46), Google Health (27) and Google Plus (54) to come to an overview of success factors associated with successful e-commerce user adoption at Google. Factors found in the literature include service quality, information quality, system quality, perceived usefulness, perceived usability, perceived enjoyment, trust, perceived risks, in addition to social and personal influences. 
Although these factors come from different theories with different backgrounds and assumptions we think that by handling them all in a qualitative interview model explains more than evaluating the new innovation with one of the underlying methods in a quantitative way. A combination would be very time consuming but would be best.

Analyzing these success factors in our interview the following findings arise. First perceived compatibility proved a good indicator of user adoption at Google and can be used to explain while certain innovations are considered useful while others are not. Second there should be a fit between information supplied and the information needs of the user. The better the fit between information needs and information provided by the ecommerce service, the higher user adoption of the service. In this case it is important to know which information users expect to get from a service and meet these expectations. Third our study showed that perceived usefulness is not only a subjective perception, but also a relative perception as in relative advantage. E-commerce ventures should not be studied as a closed system, but in the context of its competitive environment. Fourth findings suggest that risks should be in balance with trust for successful adoption of ecommerce projects. Further findings show that social pressure of using a service increases the likeliness of using the service. Google search saw some pressure, Google health no pressure and Google plus still lacks social pressure. In the case of Google Plus this social pressure is closely related to the usefulness of the service, which makes it hard to isolate the effect from social pressure from the effect of usefulness on user adoption.

With current results Google Plus is deemed to fail. A solution has to be found to overcome a lacking information quality and usefulness resulting from a lacking user adoption. Possible solutions include more radical innovations or inclusion of friends data from external sources. Looking at the interviews no single success factor on its own can explain the success or failure of a service. A service which scores high on all success factors, but is not compatible with current values and work practices will probably not be successful. The right balance of success factors is necessary for a service to be successful. Results show no significant differences in age, experience or gender supporting the generalizability of the results.

Rather than drawing on a single model or adapting a selection of success criteria, services should be evaluated based on all success criteria. The used PRIMA method is proven valuable, but could be adjusted to more explicitly measure our e-commerce success factors in a voluntary user environment. Our list of success factors could be translated in a PRIMA interview for e-commerce services by selecting different success measures for each of the individual factors. Such a list could be used to evaluate a service from the user perspective and would increase success rates of new ecommerce startups. The user adoption of e-commerce is a widely debated topic, and our study showed a wide variety of success factors all partially explaining the adoption of e-commerce. That said, the complete answer remains hidden. Till that time rather than to draw on a single model our collection of success factors can serve as a valuable guideline both for research as practice.

\section{$8 \quad$ Future Research}

In general current research fails to incorporate a sense of time, while user perceptions like usefulness and intention to use may change over time. Despite theories like 
Rogers Innovation Diffussion Theory (1983) incorporating a staged innovationdecision process, this theory didn't got much attention in studies addressing the user adoption of e-commerce. More attention should be for this changing user perception. Furthermore, existing models explore adoption of innovations as an isolated event, while the Internet constitutes a social happening with different influences including competitors, new technologies, and users among other external factors. The models use a single user as unit of analysis, in some cases using a group of users as unit of analysis may be more appropriate. Models like TAM may be over simplified for adoption of complex technologies like the Internet, but are used in most research addressing the user adoption of e-commerce. services. Finally, no single article within our literature study included all factors associated with successful user adoption of ecommerce in a single model. Future research might study if and how factors relate to each other. Finally our study illustrated the value of qualitative efforts in the area of ecommerce adoption. The Prima model should be adjusted for e-commerce specific applications and could be used in more studies. This would allow for a more detailed understanding of user motivations behind e-commerce user adoption.

\section{References}

Ackerman, M.S.L.F.: Privacy in E-Commerce: Examining User Scenarios and Privacy Preferences. In: ACM Conference on Electronic Commerce, pp. 1-8. ACM, Denver (1999)

Ahn, T., Ryu, S., Han, I.: The impact of the online and offline features on the user acceptance of Internet shopping malls. Electronic Commerce Research and Applications 3, 405-420 (2004)

Ajzen, I.: The theory of planned behavior. Organizational Behavior and Human Decision Processes 50(2), 179-211 (1991)

Aladwani, A.M., Palvia, P.C.: Developing and validating an instrument for measuring userperceived web quality. Information \& Management 39, 467-476 (2002)

Al-Gahtani, S.S.: Modeling the electronic transactions acceptance using an extended technology acceptance model. Applied Computing and Informatics 9, 47-77 (2011)

Andrea Basso, D.G.: First impressions: emotional and cognitive factors underlying judgments of trust e-commerce. In: 3rd ACM Conference on Electronic Commerce, pp. 137-143. ACM, New York (2001)

Bagozzi, R.: The legacy of the technology acceptance model and a proposal for a paradigm shift. Journal of the Association for Information Systems 8(4), 244-254 (2007)

Ball, E.F., Carla Smith, N.F., Richard, S., Bakalar, M.: Personal Health Records: Empowering Consumers. Journal of Healthcare Information Management 21(1), 76-86 (2007)

Bettina Berendt, O.G.: Privavy in e-commerce: Stated Preferences vs. Actual Behavior. Comms. ACM 48(4), 101-106 (2005)

Bhatia, B.S.: A Framework for Determining Success Factors of an E-Commerce Initiative. Journal of Internet Commerce 1(2), 63-75 (2002)

Bhattacherjee, A.: Acceptance of E-Commerce Services: The Case of Electronic Brokerages. IEEE Transactions on Systemens, Man, And Cybernetics - Part A: Systems and Humans 30(4), 411-420 (2000)

Brandeis, S.D.: The Right to Privacy. Harvard Law Review 4(5), 193-220 (1890)

Chen, L.-D., Tan, J.: Technology Adaptation in E-commerce: Key Determinants of Virtual Stores Acceptance. European Management Journal 22(1), 74-86 (2004) 
Chen, L.-D., Gillenson, M.L., Sherrell, D.L.: Enticing online customers: an extended technology acceptance perspective. Information \& Management 39, 705-719 (2002)

Chervany, D.H.: What Trust Means in E-Commerce Customer Relationships: An Interdisciplinary Conceptual Typology. International Journal of Electronic Commerce / Winter 6(2), 35-59 (2001-2002)

Collier, J.E., Bienstock, C.C.: Measuring Service Quality in E-Retailing. Journal of Service Research 8, 260 (2006)

ComScore. comScore Releases June 2012 U.S. Search Engine Rankings (July 11, 2012, ) retrieved from comScore, http://www.comscore.com/Press_Events/Press_ Releases/2012/6/comScore_Releases_June_2012_U.S._ Search_Engine_Rankings

Corritore, C.L., Kracher, B., Wiedenbeck, S.: On-line trust: concepts, evolving themes, a model. Int. J. Human-Computer Studies 58, 737-758 (2003)

Crespo, A.H.: Explaining B2C e-commerce acceptance: An integrative model based on the framework by Gatignon and Robertson. Interacting with Computer 20, 212-224 (2008)

Davis, F.D.: Perceived usefulness, perceived ease of use, and user acceptance of information technology. MIS Quarterly 13(3), 319-340 (1989)

DeLone, W.: The DeLone and McLean model of information systems success: a ten-year update. Journal of Management Information Systems 19, 9-30 (2003)

Desmedt, S.M.: Preliminary Analysis of Google+'s Privacy. In: 18th ACM Conference on Computer and Communications Security, pp. 17-21 (October 2011)

Dubinsky, Z.C.: A Conceptual Model of Perceived Customer Value in E-Commerce: A Prelimniary Investigation. Psychology \& Marketing 20(4), 323-347 (2003)

Dwivedi, Y., Rana, N., Chen, H., Williams, M.: A Meta-analysis of the Unified Theory of Acceptance and Use of Technology (UTAUT). In: Governance and Sustainability in Information Systems. Managing the Transfer and Diffusion of IT, pp. 155-170 (2011)

Eastin, M.S.: Diffusion of e-commerce: an analysis of the adoption of four e-commerce activities. Telematics and Informatics 197, 251-267 (2002)

Egger, F.N.: Affective Design of E-commerce User Interfaces: How to Maximise Perceived Trustworthiness. In: International Conference on Affective Human Factors Design. Asean Academic Press, London (2001)

Freeman, M., Hyland, P.: The current state of Australian Online Supermarket Usability. In: ACIS 2003 Proceedings. Paper 102, vol. 1 (2003)

Freudenthal, D.: Age differences in the performance of. Behaviour \& Information Technology 20(1), 9-22 (2001)

Gefen, D., Karahanna, E., Straub, D.W.: Trust and TAM in Online Shopping: An Integrated Model. MIS Quarterly 27(1), 51-90 (2003)

Google. An update on Google Health and Google PowerMeter (June 24, 2011) Retrieved from Google Official Blog, http://googleblog.blogspot.nl/2011/06/updateon-google-health-and-google.html

Google Inc. Our History in depth (August 14, 2012) retrieved from Google, http: / / www.google.com/intl/en/about/company/history/

Green, D.T., Pearson, J.M.: Integrating website usability with the electronic commerce acceptance model. Behaviour \& Information Technology 30(2), 181-199 (2011)

Griffiths, J.R.: The Commercialized Web: Challenges for Libraries and Democracy. library trends, 539-554 (2005)

Han, L., Jin, Y.: A Review of Technology Acceptance Model in the E-commerce Environment. In: International Conference on Management of e-Commerce and e-Government, pp. 28-31. IEEE, Nanchang (2009) 
Hernández, B., Jiménez, J., Martín, M.J.: Customer behavior in electronic commerce: The moderating effect of e-purchasing experience. Journal of Business Research 63, 964-971 (2010)

Hernández-García, A., Iglesias-Pradas, S., Chaparro-Peláez, J., Pascual-Miguel, F.: Perceived Compatibility and the Adoption of B2C E-Commerce by Non-buyers, Organizational, Business, and Technological Aspects of the Knowledge Society. Communications in Computer and Information Science 112, 186-192 (2010)

Hicks, M.: Plug in to customers - Usability testing, tools help prevent site flaws, reveal secrets to Web success. eWeek 19(4) (2002)

Kalakota, R.A.: Electronic Commerce: A Manager's Guide. Addison-Wesley (1997)

Karahanna, E., Agarwal, R., Angst, C.: Reconceptualizing Compatibility Beliefs. MIS Quarterly 30(4) (2006)

Kim, C., Galliers, R.D., Shin, N., Ryoo, J.-H., Kim, J.: Factors influencing Internet shopping value and customer repurchase intention. Electronic Commerce Research and Applications 11, 374-387 (2012)

Kim, H.-W., Xu, Y., Gupta, S.: Which is more important in Internet shopping, perceived price or trust? Electronic Commerce Research and Applications 11, 241-252 (2012)

Klopping, I.M., McKinney, E.: Extending the Technology Acceptance Model and the TaskTechnology Tit model to consumer e-commerce. Information Technology, Learning, and Performance Journal 22(1), 35-48 (2004)

Koufaris, M., Hampton-Sosa, W.: The development of initial trust in an online company by new customers. Information \& Management 41, 377-397 (2004)

Lee, D., Park, J., Ahn, J.-H.: On the Explanation of Factors Affecting E-Commerce Adoption. In: ICIS 2001 Proceedings. Paper 14 (2001)

Lee, G.-G., Lin, H.-F.: Customer perceptions of e-service quality in online shopping. International Journal of Retail \& Distribution Management 33(2), 161-176 (2005)

Lee, M.K., Shi, N., Cheung, C.M., Lim, K.H., Sia, C.L.: Consumer's decision to shop online: The moderating role of positive informational social influence. Information \& Management 48, 185-191 (2011)

Lee, M.-C.: Factors influencing the adoption of internet banking: An integration of TAM and TPB with perceived risk and perceived benefit. Electronic Commerce Research and Applications 8, 130-141 (2009)

Liu, C., Arnett, K.P.: Exploring the factors associated with Web site success in the context of electronic commerce. Information \& Management 38, 23-33 (2000)

McKnight, D.H., Chervany, N.L..; (2001-2002), What Trust Means in E-Commerce Customer Relationships: An Interdisciplinary Conceptual Typology,International Journal of Electronic Commerce,Volume 6, Number 2, p35-59

Miles, M.B., Huberman, A.M.: Qualitative data analysis: An expanded sourcebook. Sage (1994)

Miller, K.: Communications theories: perspectives, processes, and contexts. McGraw-Hill, New York (2005)

Pagliari, D.D.: Potential of electronic personal health records. BMJ 335, 330-333 (2007)

Pavlou, P.A.: Consumer Acceptance of Electronic Commerce: Integrating Trust and Risk with the Technology Acceptance Model. International Journal of Electronic Commerce 7(3), 69-103 (2003)

Poelhekke, K.: Over Google's personaliseringsmechanismen, de gevaren ervan en de rol van Google+ (2011)

PwC \& NVCA, MoneyTree report. PricewaterhouseCoopers $(\mathrm{PwC})$ and the National Venture Capital Association, NVCA (2011) 
Reichheld, F.F., Sasser, W.J.: Zero Defections: Quality Comes to Services. Harvard Business Review, 105-111 (1990)

Rogers, E.M.: Diffusion of Innovations. Free Press, New York (1983)

Saarinen, T., Sääksjärvi, M.: Process and product success in information systems development. Journal of Strategic Information Systems 1, 266-277 (1992)

Santos, J.: E-service quality: a model of virtual service quality dimensions. Managing Service Quality 13(3), 233-246 (2012)

Shih, H.-P.: An empirical study on predicting user acceptance of e-shopping on the Web. Information Management 41, 351-368 (2004)

Spiekermann, J.G.: E-privacy in 2nd Generation E-Commerce: Privacy Preferences versus actual Behavior. In: EC 2001, October 14-17. ACM, Tampa (2001)

Spil, T.A., Schuring, R.W., Michel-Verkerke, M.B.: Electronic prescription system: do the professionals USE IT? Int. J. Healthcare Technology Management 6(1), 32-55 (2004)

Spil, T.A., Michel-Verkerke, M.B.: De waarde van informatie in de gezondheidswereld, Eburon, Delft (2012)

Sunyaev, D.C.: Evaluation Framework for Personal Health Records: Microsoft HealthVault vs. Google Health. In: 43rd Hawaii International Conference on System Sciences, pp. 1-10 (2010)

Turban, M.K.: A Trust Model for Consumer Internet Shopping. International Journal of Electronic Commerce 6, 75-91 (2011)

Udo, G.J.: Privacy and security as mojor barriers for e-commerce: a survey study. Information Management \& Computer Security, 165-174 (2001)

Urbach, N., Muller, B.: The Updated DeLone and McLean Model of Information Systems Success. Information Systems Theory Integrated Series in Information Systems 28, 1-18 (2012)

Venkatesh, V.A.: A theoretical extension of the Technoly Acceptance Model: Four longitudal field studies. Management Science 46(2), 186-204 (2000)

Venkatesh, V., Morris, M.G., Davis, G.B., Davis, F.D.: User Acceptance of Information Technology: Toward a Unified View. MIS Quarterly 27(3), 425-478 (2003)

Wang, Y.-S.: Assessing e-commerce systems success: a respecification and vali on of the DeLone and McLean model of IS success. Info Systems 18, 529-557 (2008)

Yin, R.K.: Case study research: Design and methods, 2nd edn. Sage, Thousand Oaks (1994)

Zeithaml, V.A., Parasuraman, A., Malhotra, A.: Service Quality Delivery Through Web Sites: A Critical Review of Extant Knowledge. Journal of the Academy of Marketing Science 30(4), 362-375 (2002)

Zeuthaml, V., Berry, L., Parasuraman, A.: The behavior consequences of service quality. Journal of Marketing 60, 31-46 (1996)

Zhou, T., Zhang, S.: Examining the Effect of E-commerce Website Quality on User Satisfaction. In: Second International Symposium on Electronic Commerce and Security, pp. 418-421. IEEE, Nanchang (2009)

Zwass, V.: Electronic commerce: structures and issues. International Journal of Electronic Commerce 1(1), 3 (1996) 